\title{
Effects of Water Temperature on Prey-Predator Interactions of Yellowfin Sole Limanda aspera
}

\author{
Kohei Kihara*1 and Allen M. Shimada*2 \\ (Received September 13, 1988)
}

\begin{abstract}
The dynamics of trophic relationships between prey and predator of yellowfin sole and influence of bottom water temperature upon them were examined in the eastern Bering Sea during summers from 1979 to 1984 . Yellowfin sole were classified by sex and fork length. Mutual occurrences between yellowfin sole (male 11-25 cm, female 16-20,26-30 cm) and capelin were found to vary with bottom temperature significantly. Area overlaps between yellowfin sole and most species were not correlated with ambient temperature. This fact suggests that mutual occurrence is due to other biological or physical considerations related to the intrinsic requirements of each species. This study has elucidated that some coexistences of prey and predators which facilitate predation to a greater degree were affected by bottom water temperature.
\end{abstract}

Feeding interactions between predator, prey, and competitor have biological significance in the marine ecosystem. The dynamics of trophic relationships may be influenced not only by individual physiological requirements, but also by the degree of temporal and spatial overlap in species occurrence. Earlier studies in the eastern Bering Sea have described changes to demersal community structure corresponding with fluctuations in water temperature and salinity. ${ }^{1-3}$ ) While other investigators have focused on trophic studies of principal eastern Bering Sea groundfish to characterize species-specific food habits, ${ }^{* 3,4-7)}$ a prior study examined the influence of bottom water temperature on the trophic relationships of walleye pollock Theragra chalcogramma.*4 This paper extends the study to the influence of water temperature on species interactions of yellowfin sole Limanda aspera to further test the hypothesis that mutual occurrence between predator and prey is affected by the abiotic environment. Yellowfin sole are the most abundant flounder in the eastern Bering Sea, and the second most abundant demersal fish after walleye pollock..$^{8)}$

\section{Materials and Methods}

Catch information for groundfish species was obtained from annual resource assessment trawl surveys conducted by the Northwest and Alaska Fisheries Center (NWAFC) between May and August from 1979 to 1984 . Bottom tows of 30minutes duration were conducted at stations spaced 20 nautical miles apart over the eastern shelf (Fig. 1). The numbers of successful trawl stations included in the analysis were 317 (1979), 311 (1980), 280 (1981), 314 (1982), and 324 (1984), respectively. The sampling protocol and characteristics of the vesseles and trawl gears used each year are described in data reports issued by the NWAFC. ${ }^{9)}$ Water temperatures on bottom were obtained by expendable bathythermograph (XBT) at each station.

The major predators of yellowfin sole examined in this study were: ${ }^{* 4,5-7)}$ Pacific halibut Hippoglossus stenolepis (fork length $>41 \mathrm{~cm}$ ), Pacific cod Gadus macrocephalus (male \& female $>56 \mathrm{~cm}$ ), warty sculpin Myoxocephalus verrucosus, plain sculpin Myoxocephalus joak. Yellowfin sole prey included juvenile walleye pollock (male \& female $<20 \mathrm{~cm}$ ), tanner crab Chionoecetes opilio, hermit

*1 Tokyo University of Fisheries, Konan, Minato, Tokyo 108, Japan (木原興平: 東京水産大学).

*2 Northewst and Alaska Fisheries Center, NOAA, Sand Point Way N.E., Seattle, Washington 98115 , U.S.A. (Allen M. Shimada: 米国・北西・アラスカ水産センター).

* K. Mito: Food relationships among benthic fish populations in the Bering Sea: on the Theragra chalcogramma fishing grounds in October and November of 1972, Master Thesis, Hokkaido Univ., Japan, 135 p (1974).

*4 M.S. Yang: Food habits and daily ration of Greenland halibut Reinhardtius hippoglossoides in the eastern Bering Sea, Master Thesis, Univ. Washington, 57 p. (1987). 


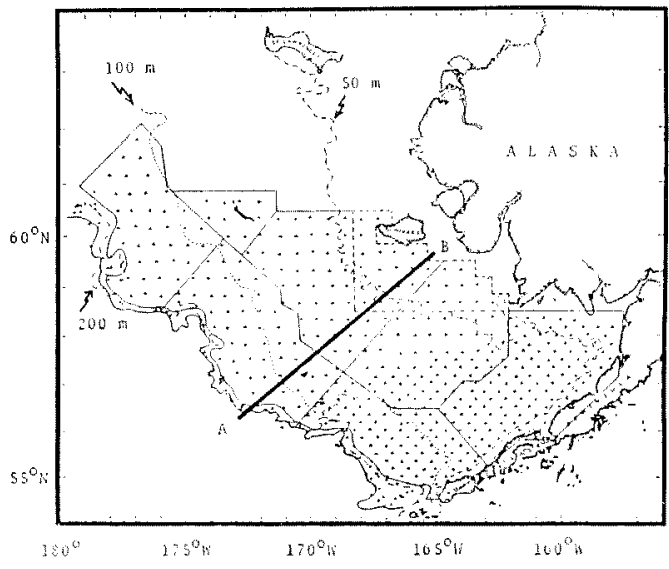

Fig. 1. Survey area and fixed trawl sampling stations occupied each summers from 1979 to 1984. $A B$ line divides the shelf into the northwest and the southeast regions.

crab Pagurus spp., rainbow smelt Osmerus mordax, capelin Mallotus villosus, Pacific sand lance Ammodytes hexapterus. ${ }^{* 1,5-7)}$

Yellowfin sole were classified by sex into $5 \mathrm{~cm}$ fork length intervals (male: $6-40 \mathrm{~cm}$, female: 7 $44 \mathrm{~cm}$ ).

An affinity index was calculated to characterize the degree of coexistence among species. ${ }^{10,11}$ This index is expressed by the geometric mean of the proportion of joint occurrence, corrected for sample size: $c / \sqrt{a b}-1 / 2 \sqrt{b}$, where $c$ is the number of joint occurrences; $a$ and $b$ are the total numbers of occurrences of species A and B respectively. The letter $a$ is less than or equal to $b$. Because this analysis is computed on the basis of presence or absence of the species in each trawl sample, and not by weight or number, their relative abnudances are not considered in the index. This study defined the number of occurrences of each species as the number of stations where it represented a recorded catch weight $\geq 45 \mathrm{~g}$. This is the minimum value carried in the NWAFC computer data base. The affinity indices were calculated for all possible species combinations.

Mean bottom water temperatures were calculated for the overall, northwest and southeast regions of the eastern Bering Sea. These regions were separated by the $\mathrm{AB}$ line shown in Fig. 1.4)

\section{Results and Discussion}

This study regarded bottom water temperature as one readily obtained parameter of the abiotic marine environment. As referred in our former studies, mean bottom water temperatures changed over a two year cycle. The overall mean water temperature of the coldest year was $2.1^{\circ} \mathrm{C}$ in 1984 . That of the warmest year was $4.5^{\circ} \mathrm{C}$ in $\left.1979 . .^{3,4}\right)$

Species pairs which demonstrated high indices of affinity through each of the six years included: yellowin sole (male \& female $21-25 \mathrm{~cm}$, female $31-34 \mathrm{~cm}$ ) and juvenile walleye pollowck (male $<20 \mathrm{~cm}$ ); yellowfin sole (male \& female 16$35 \mathrm{~cm}$ ) and large sculpins; yellowfin sole (male \& female $16-30 \mathrm{~cm}$, female $31-35 \mathrm{~cm}$ ) and hermit crabs; and yellowfin sole (male \& female 16$30 \mathrm{~cm}$ ) and capelin. No other species combinations were found to be significant. Ranges of the affinity indices (AI) of major species pairs were as following: capelin and yellowfin sole (male 11-15 cm, AI: 0-0.51; male 16-20 cm, AI: 0.33-0.66; amle 21-25 cm, AI: 0.4-0.72; female 16-20 cm, AI: 0.32-0.76; female $26-30 \mathrm{~cm}, \mathrm{AI}$ : $0.38-0.72$ ), and walleye pollock (female $>56 \mathrm{~cm}$ ) and yellowfin sole (male $21-25 \mathrm{~cm}, \mathrm{AI}$ : $0-0.67$; female $16-20 \mathrm{~cm}, \mathrm{AI}$ : $0-0.53$; female $21-25 \mathrm{~cm}$, AI: 0-0.72; female $26-30 \mathrm{~cm}$, AI: $0-0.68$ ). Pacific cod rely on yellowfin sole for a portion of their diet, but no significant affinities were found in this study based on recurrent group analysis. Similarly, Pacific sand lance and Tanner crab were not strongly paired with yellowfin sole. Area overlaps between yellowfin sole (male \& female 11-15 $\mathrm{cm}$ ) and Pacific halibut (unknown sex $46-50 \mathrm{~cm}$ ) were not large but were positively correlated with bottom water temperature.

To examine the influence of water temperature on the coexistence of yellowfin sole and the significant species relationships found here, correlation coefficients were calculated between the affinity indices of species pairs and bottom temperatures (Fig. 2).

Area overlaps between yellowfin sole and capelin were found to vary with temperature. The occurrence number of yellowfin sole (female 26$30 \mathrm{~cm}$ ) and the mean bottom temperature was correlated at -0.86 for overall shelf mean $(p<$ $0.05)$ and -0.84 for northwest shelf mean $(p<$ 0.05 ). The occurrence number of capelin and the mean bottom temperature correlated at -0.97 for

* 1 M.S. Yang: Food habits and daily ration of Greenland halibut Reinhardtius hippoglossoides in the eastern Bering Sea, Master Thesis, Univ. Washington, 57 p. (1987). 


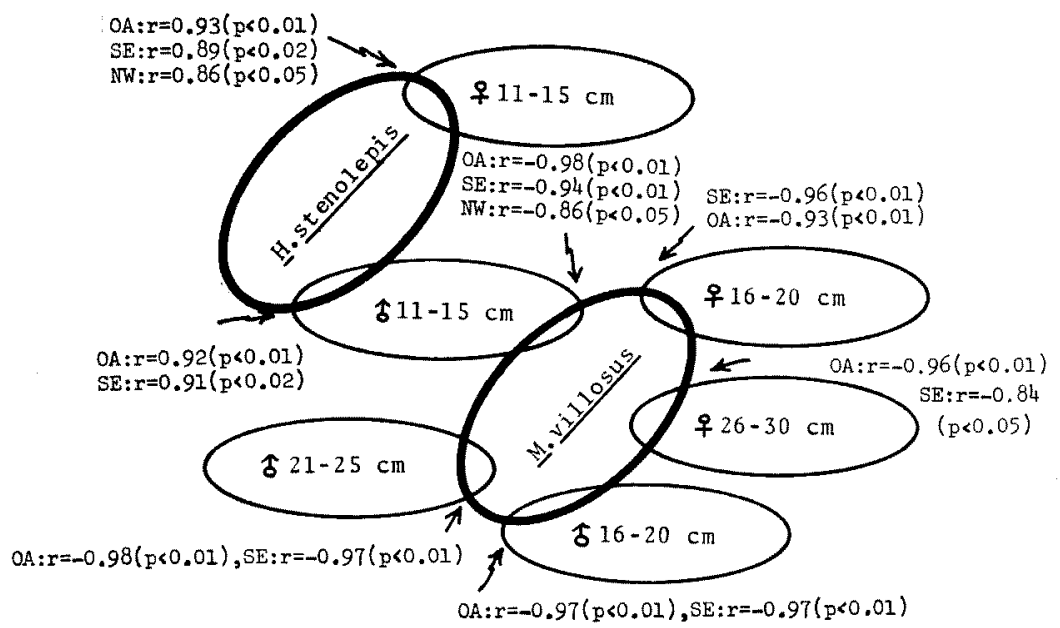

Fig. 2. Major relationshps (correlation coefficient $r>0.84$ ) between common occurrences of major yellowfin sole prey-predators and yellowfin sole of different sex and siz and mean bottom water temperatures (OA: overall shelf, NW: northwest shelf, SE: southeast shelf) of the eastern Bering Sea during summers of 1979 to 1984 . Ellipses represent habitats of predator and prey, and yellowfin sole groups by sex and size.?: unknown sex.

northwest shelf mean $(p<0.01)$ and -0.93 for overall shelf mean $(p<0.01)$. Yellowfin sole (male 11-25 cm, female $16-20,26-30 \mathrm{~cm}$ ) co-occurred with capelin, and their affinity indices decreased with respect to prevailing bottom temperatures. Thus, the area of mutual coexistence is thought to constract in warm years and increase in cold water years.

Distribution of female yellowfin sole $(21-35 \mathrm{~cm})$ was negatively correlated with northwest and overall shelf temperature. However, the affinity indices between large sculpins and female yellowfin sole $(21-35 \mathrm{~cm})$ did not hang with variations in bottom temperature. Although yellowfin sole distribution was found to expand or contract in accordance with bottom temperature, there was no relationship between the coexistence of yellowfin sole and sculpins, and water temperature.

Yellowfin sole (male $21-25 \mathrm{~cm}$, female $31-$ $35 \mathrm{~cm}$ ) and small walleye pollock (male $<20 \mathrm{~cm}$ ) were paired strongly, but no significant correlations were found between these indicaes and bottom temperatures. Studies by P. A. Livingston et al. indicated that yellowfin sole larger than $25 \mathrm{~cm}$ depend on juvenile pollowck for as much as $1.5 \%$ of their body weight during summer. ${ }^{3)}$ The coexistence of this pair, without any significant relationship to temperature variation, suggests other grounds for yellowfin sole predation on juvenile pollock.
The relationship between yellowfin sole (male \& female $16-35 \mathrm{~cm}$ ) and hermit crab did not change with shifts in water temperature. The coexistence of this pair indicated by their high affinity indices is not dependent on observed temperature regimes. Although Pacific halibut (unknown sex $46-50 \mathrm{~cm}$ ) and yellowfin sole (male \& female $11-15 \mathrm{~cm}$ ) did not coexist so much, coexistences of these pairs were dependent on bottom temperatures (Fig. 2).

The coexistences of predators and prey of yellowfin sole in the eastern Bering Sea are supposed to be affected by abiotic environmental factors other than bottom water temperature, and multiple biological processes. However, this study elucidated influence of water temperature which is one of the abiotic environmental factors upon associations of predators and prey of yellowfin sole. Predation on yellowfin sole is facilitated when predators can coexist to a greater degree under favorable bottom temperatures. Similarly, yellowfin sole prey coexist in a large habitat area under favorable temperature regimes, as found for middle sizes of yellowfin sole and capelin. Where there are no meaningful correlations between high affinity indices and bottom temperature, it is likely that mutual occurrence is due to other biolgical or physical considerations related to the intrinsic requirements of each species. 


\section{Acknowledgment}

The authors would like to appreciate assistance by Prof. Dr. W. S. Wooster, University of Washington.

\section{References}

1) K. Kihara: Nippon Suisan Gakkaishi, 49, 41-47 (1983).

2) K. Kihara: Nippon Suisan Gakkaishi, 49, 4954 (1983).

3) K. Kihara and A. M. Shimada: Bull. Int. North Pacific Fish. Comm., 47, 31-48 (1986).

4) K. Kihara and A. M. Shimada: Nippon Suisan Gakkaishi, 54, 1131-1135 (1988).

5) P. A. Livingston, D. A. Dwyer, D. L. Wencker, M.S. Yang, and G. M. Lang: Bull. Int. North
Pacific Fish. Comm., 47, 49-65 (1986).

6) K. Wakabayashi: Bull. Int. Pacific Fish. Comm., 47, 3-30 (1986).

7) S. J. Salveson and M.S. Alton: Northwest \& Alaska Fish. Center Processed Report, 439-459 (1976).

8) R. G. Bakkala: in "The Eastern Bering Sea Shelf: Oceanography and Resource" (ed. by D. W. Hood and J. A. Calder), Vol. 1, U. S. Dep. Commer., 1981, pp. 553-574.

9) R. G. Bakkala, J. J. Traynor, K. Teshima, A. M. Shimada, and H. Yamaguchi: U.S. Dep. Commer., NOAA Tech. Memo. NMFS F/NWC. 87, 1-448 (1985).

10) E. W. Fager: Ecology, 38(4), 586-595 (1957).

11) E. W. Fager: in "The Sea" (ed. by M. N. Hill), Vol. 2, Interscience, London, 1963, pp. 415-437. 